\title{
Peningkatan Inklusivitas Ekonomi Melalui Pembiayaan Investasi Modal Manusia
}

\author{
Visi Saujaningati Kristyanto \\ Faculty Economics and Business Brawijaya \\ University \\ visisau@gmail.com \\ David Kaluge \\ Faculty Economics and Business Brawijaya \\ University \\ davidk@ub.ac.id
}

\begin{abstract}
ABSTRAK
Saat ini, pertumbuhan inklusif menjadi isu utama dalam pembangunan ekonomi. Pertumbuhan inklusif mendorong setiap individu untuk mengakses pendidikan, kesehatan dan komponen lainnya yang menunjang standar hidup yang lebih baik. Di Jawa Timur, pertumbuhan ekonomi yang tinggi diikuti dengan tingkat ketimpangan pendapatan yang tinggi. Peran pemerintah dibutuhkan untuk mendorong pertumbuhan yang lebih berkualitas melalui adanya pembiayaan investasi dalam bentuk investasi pendidikan dan kesehatan. Tujuan dari penelitian ini adalah (i) untuk mengetahui hubungan antara pembiayaan investasi modal manusia dengan pertumbuhan ekonomi dan (ii) untuk mengetahui dampak pembiayaan investasi modal manusia terhadap inklusivitas pertumbuhan di Jawa Timur. Metode analisis menggunakan metode regresi simultan dengan dua persamaan utama. Hasil temuan menunjukkan bahwa pembiayaan investasi modal manusia berpengaruh secara signifikan terhadap pertumbuhan ekonomi. Temuan kedua menjelaskan bahwa inklusivitas dapat terjadi apabila pemerintah mendorong efektivitas pembiayaan sektor pendidikan yang masih terbatas pada peningkatan kuantitas namun lemah dalam kualitas dan produktivitas sektor pendidikan. Sehingga kapasitas sumberdaya manusia yang ada saat ini tidak mampu mendorong terciptanya inklusivitas pertumbuhan di Jawa Timur.
\end{abstract}

Keywords: pertumbuhan inklusif, pembiayaan pemerintah, investasi modal manusia,

\begin{abstract}
Inclusive growth is a major issue in economic development. Inclusive growth encourages individuals to access education, health and other components that support a better standard of living. In East Java, high economic growth is followed by a high level of income inequality. The role of government is needed to encourage more quality growth through investment financing in the form of education and health investments. The purpose of this study is (i) to determine the relationship between financing of human capital investment and economic growth and (ii) to determine the impact of financing human capital investment on growth inclusiveness in East Java. The analysis method uses simultaneous regression method with two main equations. The findings show that financing of human capital investment has a significant effect on economic growth. The second finding explains that inclusiveness can occur if the government encourages the effectiveness of financing the education sector which is still limited to increasing quantity but weak in the quality and productivity of the education sector. So that the existing human resource capacity is not able to encourage the creation of growth inclusiveness in East Java.
\end{abstract}

Keyword:

Latar belakang

Terdapat perdebatan diantara para perencana pembangunan dimana kesuksesan pemerintah dalam meningkatkan pertumbuhan seringkali tidak dibarengi dengan peningkatan kesejahteraan masyarakatnya. Kesejahteraan masyarakat 
Gambar 1. Indikator Kesejahteraan di Jawa Timur

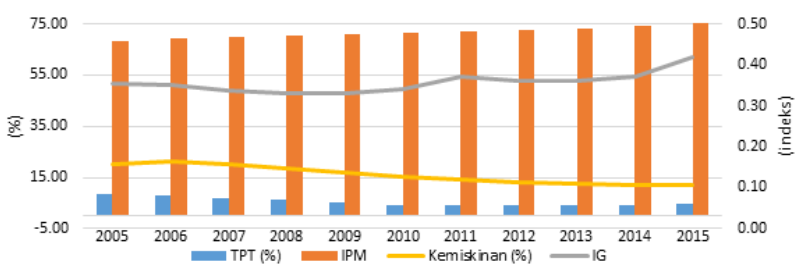

Sumber: BPS data diolah, 2016

dapat diukur melalui beberapa indikator seperti penurunan tingkat pengangguran, ketimpangan pendapatan dan kemiskinan. Studi empiris di Botswana tahun 2014 menjelaskan bahwa alokasi investasi publik untuk pendidikan gagal menurunkan tingkat pengangguran. Implikasinya, banyak penduduk berusia produktif tidak menerima pekerjaan yang layak dengan standar hidup yang tidak layak (Wilfred, 2014). Di India, laju pertumbuhan ekonomi sebesar 9\% tidak sebanding dengan penurunan kemiskinan sebesar 28\% (Pandey, 2014). Studi lainnya di Filipina menunjukkan sebagian besar masyarakat tidak merasakan keuntungan dari pesatnya pertumbuhan ekonomi. Menurut Felipe (2012), tercatat bahwa tingkat kemiskinan dan tingkat pengangguran tidak mengalami penurunan yang signifikan.

Sejak tahun 2007, telah diperkenalkan sebuah konsep untuk mengukur kesejahteraan masyarakat yang lebih komprehensif. Konsep ini dikenal dengan pertumbuhan inklusif. Menurut Asian Development Bank, pertumbuhan ekonomi tanpa diimbangi dengan peluang yang sama bagi masyarakat untuk mengakses pendidikan, kesehatan dan kesempatan kerja hanya akan memperlebar jurang kemiskinan. World Bank menambahkan tujuan untuk mencapai pertumbuhan inklusif sebagai kebijakan dalam mengurangi kemiskinan (Felipe, 2007). Dengan kata lain, pertumbuhan inklusif diharapkan mampu memberikan peluang bagi masyarakat khususnya masyarakat menengah ke bawah untuk mendapatkan standar hidup yang baik seperti pendidikan dan kesehatan serta kesempatan kerja yang lebih menjamin penghidupan. Pada akhirnya pertumbuhan inklusifbertujuan untuk mengurangi jurang-jurang ketimpangan pendapatan antar masyarakat.

Pemerintah Jawa Timur telah memfokuskan kebijakannya untuk meningkatkan pertumbuhan yang lebih inklusif sejak tahun 2014. Meski demikian, gambaran diatas menunjukkan bahwa pembangunan di Jawa Timur masih menghadapi persoalan kualitas pertumbuhan ekonomi yang belum berdampak pada masyarakat miskin. Gambar 1 menunjukkan pola indikator kesejahteraan yang meliputi tingkat pengangguran, tingkat ketimpangan pendapatan, indeks pembangunan manusia (IPM) dan indeks ketimpangan (IG). Dari tahun 2005-2015, indeks pembangunan manusia terus mengalami peningkatan meskipun tidak terlalu signifikan. Demikian halnya dengan pengurangan tingkat pengangguran dan kemiskinan. Namun, tahun 2015 tercatat bahwa jurang ketimpangan pendapatan makin melebar. Hal ini mengindikasikan adanya kedalaman kemiskinan yang makin parah.

Seperti dijelaskan dalam pertumbuhan neoklasik Solow (1956), faktor yang menentukan pertumbuhan ekonomi antara lain modal fisik, modal manusia, dan penggunaan teknologi. Model pertumbuhan Solow berbasis pada perhitungan identitas fungsi produksi Cobb-Douglas $Y=f(K, L)$. Dimana elastisitas output $(\mathrm{Y})$ bergantung pada modal fisik (K) dan modal manusia (L). Model Solow diterima untuk menganalisis hubungan antara modal manusia dengan pertumbuhan ekonomi. Meski demikian, kerangka pikir tersebut tidak selalu konsisten dengan kenyataan empiris di suatu daerah. Kemudian model Solow dikembangkan oleh Lucas (1988) dengan sebutan pertumbuhan endogen yang memberikan pemahaman lebih mendalam dari pembentukan pertumbuhan ekonomi (Wilfred, 2014).

Penelitian ini berupaya mengisi kesenjangan antara teori pertumbuhan Solow dengan studi empiris di provinsi Jawa Timur berdasarkan pada dua tujuan utama, yaitu (i) untuk mengetahui hubungan antara pembiayaan investasi modal manusia dengan pertumbuhan ekonomi dan (ii) untuk mengetahui dampak pembiayaan investasi modal manusia terhadap inklusivitas pertumbuhan di Jawa Timur.

\section{Kajian Pustaka}

Model pertumbuhan ekonomi terus berkembang dari jaman ke jaman. Dimulai dengan konsep pertumbuhan makroekonomi oleh Keynes (1936). Dalam tiga tahun selanjutnya, HarrodDomar (1939) mengembangkan variabel investasi sebagai faktor yang menentukan pertumbuhan. Selanjutnya tahun 1956, Solow memperkenalkan model pertumbuhan neoklasik dan dikembangkan 
lagi oleh Lucas (1988) dalam model pertumbuhan endogen. Sebagai grand theory dalam penelitian ini, digunakan basis model pertumbuhan neoklasik yang dikembangkan dalam model pertumbuhan endogen.

Dalam model Solow terdapat beberapa asumsi: (i) output (Y) bergantung pada modal fisik (K), modal manusia (L) dan tingkat teknologi (A); (ii) terjadi penurunan pengembalian marginal akumulasi faktor produksi yang berarti adanya tambahan modal yang makin meningkatkan output; serta (iii) faktor selain modal dan tenaga kerja dianggap tidak terlalu penting dalam proses pertumbuhan. Tingkat pertumbuhan per kapita dalam jangka panjang ditentukan oleh tingkat penggunaan teknologi dan laju pertumbuhan penduduk. Menurut Grenade (2011), peranan pemerintah untuk meningkatkan pertumbuhan ekonomi diukur melalui adanya variabel teknologi dalam model neoklasik. Penggunaan teknologi dijelaskan sebagai barang publik alamiah.

Penggunaan teknologi dalam model neoklasik dikembangkan oleh Lucas (1988) dengan konsep pertumbuhan endogen. Percepatan pertumbuhan ekonomi bergantung pada investasi modal manusia, inovasi dan research and development $(\mathrm{RnD})$. Hal ini mengindikasi bahwa akumulasi modal dan tenaga kerja penting dalam menciptakan pertumbuhan, namun diperlukan adanya investasi yang mendorong pada peningkatan produktivitas modal dan tenaga kerja. Sebagai pengembangan dari pertumbuhan neoklasik, keterkaitan antara modal manusia dengan pertumbuhan ekonomi dapat menciptakan pertumbuhan ekonomi yang berkualitas. Menurut Romer (1994), alokasi untuk investasi modal manusia dibandingkan pada modal fisik memiliki dampak spillover pada peningkatan penggunaan teknologi. UNU-IHDP dalam Inclusive Wealth Report 2014 menambahkan konsep pengukuran indeks kesejahteraan inklusif dengan tiga indikator, yaitu: (i) sumber daya alam meliputi nilai tambah sektor pertanian, tambang, harga dan sewa, produksi dan cadangan sumberdaya, (ii) sumber daya manusia meliputi tingkat pendidikan, kesehatan, upah dan gaji, jumlah tenaga kerja, gender, dan (iii) sumberdaya buatan meliputi investasi, tingkat depresiasi, dan infrastruktur.

Beberapa penelitian terdahulu mengemukakan bahwa terdapat hubungan positif antara investasi modal manusia dengan pertumbuhan ekonomi. Santos (2011) menjelaskan bahwa terdapat hubungan secara kuantitas dan kualitas adanya pendidikan terhadap pertumbuhan inklusif berbasis pada teori Solow. Selain itu ditemukan bahwa peranan pemerintah dalam mengalokasikan investasi pendidikan dapat mempercepat pertumbuhan inklusif di suatu daerah. Pritchett (2001) dan Levine (2001) menunjukan bahwa tidak adanya hubungan yang signifikan antara akumulasi modal fisik dengan pertumbuhan ekonomi. Pertumbuhan ekonomi justru diciptakan dari adanya peningkatan investasi pada modal manusia.

Odit et al. (2010) dan Safdari et al. (2010) menjelaskan bahwa ada pengaruh akumulasi modal manusia terhadap pertumbuhan ekonomi dengan ukuran rasio penduduk berpendidikan tinggi. Pendidikan yang tinggi mencerminkan tingkat penggunaan teknologi yang lebih tinggi. Dimana, di negara berkembang penggunaan teknologi ini tidak terlalu signifikan meningkatkan pertumbuhan ekonomi dibandingkan negaranegara maju. Hal ini terjadi karena rasio penduduk berpendidikan tinggi masih sangat minim dibandingkan total populasi. Pritchett (2001) menambahkan bahwa pendidikan yang tinggi akan meningkatkan pendapatan secara individu namun berdampak pada tingginya penawaran tenaga kerja berskill yang justru menyebabkan ketimpangan pendapatan.

Dalam konsep pertumbuhan inklusif turut dijelaskan mengenai hubungan antara modal manusia dan tingkat pengangguran. Dimana peningkatan akumulasi modal manusia berdampak pada pengurangan pengangguran di suatu daerah (Charles et al., 2010; Mroz \& Savage, 2006). Ho dan Tan (2008) menambahkan, adanya akumulasi modal manusia dalam bentuk transfer pengetahuan dan informasi serta peningkatan keterampilan akan meningkatkan kapasitas dan mendorong seseorang mendapatkan pekerjaan yang layak. Terdapat hubungan antara modal manusia dengan tingkat kemiskinan. Hipotesis ini menunjukkan bahwa peningkatan modal manusia berdampak pada peningkatan upah yang diterima dan berdampak pada pengurangan kemiskinan Azam (2011). Salah satu komponen lain dalam kesejahteraan adalah ketimpangan pendapatan. Yang et. Al (2009) menjelaskan adanya hubungan antara ketimpangan 
pendidikan dengan ketimpangan pendapatan di China. Ketimpangan pendidikan dapat membuat seseorang kesulitan meningkatkan pendapatannya, sebaliknya pendapatan yang rendah membuat seseorang makin sulit mengakses pendidikan yang tinggi.

Fontana dan Srivastava (2009) meneliti "empat macan" Asia yaitu Hongkong, Korea Selatan, Singapura, dan Taiwan yang menghadapi persoalan tingginya pertumbuhan ekonomi disertai ketimpangan pendapatanyang makin lebar. Dengan adanya alokasi investasi pada modal manusia, negara tersebut tidak hanya mampu mengurangi kemiskinan namun juga meningkatkan akumulasi modal fisik. Hal ini menyebabkan tenaga kerja diberikan upah yang layak untuk meningkatkan produktivitas tenaga kerja dan standar hidup yang lebih baik.

\section{Metode Penelitian}

Pendekatan penelitian ini adalah pendekatan kuantitatif dengan berfokus pada satu daerah (single country) yaitu provinsi Jawa Timur pada rentangan waktu analisis yaitu tahun 2004 - 2015 (time series data). Pendekatan ini dipilih dengan tujuan untuk dapat merekomendasikan kebijakan publik yang relevan dan spesifik dalam upaya mewujudkan pertumbuhan inklusif di Jawa Timur. Metode pengumpulan data adalah dengan mendokumentasikan data-data sekunder yang bersumber dari World Bank dan Badan Pusat Statistik Provinsi Jawa Timur. Metode analisis menggunakan analisis regresi simultan three least square. Terdapat dua persamaan utama yang diolah dalam model logaritma, yaitu:

(i) regresi linear berganda untuk mengetahui hubungan antara pembiayaan investasi modal manusia dengan pertumbuhan ekonomi.

$\lg r_{t}=\alpha_{1}+\alpha_{2} \lg r_{t-1}+\alpha_{3} \operatorname{lcap} t_{t}+\alpha_{4} \operatorname{lman} n_{t}+\alpha_{5} \operatorname{lgved}_{t}+\alpha_{6} \operatorname{lgvt} t+$ $e_{t}$

(ii) regresi untuk mengetahui bagaimana dampak pembiayaan investasi modal manusia terhadap inklusivitas pertumbuhan

$\mathrm{ik}=\beta_{1}+\beta_{2} \lg \mathrm{r}_{\mathrm{t}-1}+\beta_{3} \operatorname{lman}_{\mathrm{t}}+\beta_{4} \operatorname{lgved}_{\mathrm{t}}+\beta_{5} \operatorname{lgvhe}_{\mathrm{t}}+\mathrm{e}_{\mathrm{t}}$

Dimana ik merupakan indeks inklusivitas yang diukur berdasarkan rasio pertumbuhan ekonomi per ketimpangan pendapatan. Semakin tinggi nilainya maka pertumbuhan ekonomi mengarah pada inklusif, sedangkan semakin rendah nilai indeks maka pertumbuhan ekonomi makin tidak inklusif.

Dengan definisi operasional sebagai berikut:

Variabel Definisi

gr : pertumbuhan ekonomi pada

tahun tertentu

grt-1 : pertumbuhan ekonomi pada tahun sebelumnya

cap : akumulasi modal fisik pada tahun tertentu

man : kualitas modal manusia pada tahun tertentu

gved : pembiayaan pemerintah untuk pendidikan

gvsoc : pembiayaan pemerintah untuk kesehatan

gvt : pembiayaan pemerintah untuk pendidikan dan kesehatan

ik : indeks inklusivitas dihitung berdasarkan rasio pertumbuhan per ketimpangan pendapatan.

\section{Hasil dan Pembahasan}

Variabel teknologi dalam model pertumbuhan endogen diartikan sebagai komponen yang menentukan percepatan pertumbuhan ekonomi selain dari adanya akumulasi modal fisik dan modal manusia. Penelitian ini berfokus pada kinerja investasi non fisik yang dikenal dengan nama investasi sumber daya manusia. Pembiayaan investasi sumber daya manusia (investasi modal manusia) merupakan sejumlah dana yang dikeluarkan dan kesempatan memperoleh penghasilan selama proses investasi yang bertujuan untuk meningkatkan kualitas manusia (Becker, 1964). Pembiayaan investasi modal manusia dapat berupa investasi pendidikan, kesehatan, jaminan sosial, infrastruktur dan lain sebagainya.

Berdasarkan tabel 1, pengujian chi-kuadrat pada kedua persamaan memiliki probabilitas kurang dari alpha 5\% yang berarti persamaan ini memenuhi uji goodness of fit dan uji interdependensi. Dengan demikian persamaan ini dianggap valid untuk menjelaskan permasalahan penelitian yang ada. Untuk mengetahui adanya hubungan antara 
Tabel 1. Hasil Regresi Simultan

\begin{tabular}{|c|c|c|c|c|c|}
\hline Variabel & Koefisien & $\mathrm{P}>|\mathrm{t}|$ & Standar Eror & $\mathrm{R}-\mathrm{sq}$ & $\mathrm{P}$ \\
\hline \multicolumn{6}{|c|}{ Persamaanl: Pertumbuhan Ekonomi } \\
\hline konstanta & $5.89 * * *)$ & Sig & 2.27 & 0.46 & ** \\
\hline Pert. Eko lampau & 0.13 & Tidak sig & 0.23 & & \\
\hline Modal fisik & 0.19 & Tidak sig & 0.24 & & \\
\hline Modal manusia & $\left.-4.43^{* *}\right)$ & Sig & 2.20 & & \\
\hline Pemb. pendidikan & $\left.-0.21^{* *}\right)$ & Sig & 0.10 & & \\
\hline Pemb. investasi modal manusia & $0.28 * *)$ & Sig & 0.09 & & \\
\hline \multicolumn{6}{|c|}{ Persamaan 2: Pertumbuhan Inklusif } \\
\hline Konstanta & $11.55 * * *)$ & Sig & 2.28 & 0.65 & $* * *$ \\
\hline Pert. Eko lampau & -0.04 & Tidak sig & 0.28 & & \\
\hline Modal manusia & $6.25 * * *)$ & Sig & 1.29 & & \\
\hline Pemb. Pendidikan & $0.22 * * *)$ & Sig & 0.08 & & \\
\hline Pemb. Kesehatan & $0.31 * *)$ & Sig & 0.07 & & \\
\hline
\end{tabular}

pembiayaan investasi modal manusia dengan pertumbuhan ekonomi digunakan metode analisis regresi pada persamaan pertama. Persamaan ini merupakan persamaan yang berbasis pada model pertumbuhan endogen dimana pertumbuhan ekonomi dipengaruhi oleh akumulasi modal fisik, kualitas modal manusia, dan adanya teknologi berupa pembiayaan investasi modal manusia pada bidang pendidikan dan kesehatan.

Secara parsial, pertumbuhan ekonomi pada tahun sebelumnya dan akumulasi modal fisik tidak berpengaruh secara signifikan terhadap pertumbuhan ekonomi Jawa Timur. Diperkuat dengan adanya penelitian terdahulu dari Levine (2001) yang menjelaskan bahwa tidak adanya hubungan yang signifikan antara akumulasi modal fisik dengan pertumbuhan ekonomi. Dikarenakan pertumbuhan ekonomi justru diciptakan dari adanya peningkatan kualitas modal manusia. Namun, hasil statistik menunjukan bahwa baik kualitas modal manusia maupun investasi pendidikan berpengaruh secara negatif terhadap pertumbuhan ekonomi. Nampaknya terdapat persoalan serius dalam kualitas sumberdaya manusia di Jawa Timur. Setiap peningkatan modal manusia sebesar $1 \%$ justru mengurangi pertumbuhan ekonomi sebesar 4.4\%.. Ketidaksesuaian teori peningkatan kualitas modal manusia yang mendorong pertumbuhan ekonomi dijelaskan oleh Pritchett (2001) bahwa pendidikan yang tinggi akan meningkatkan pendapatan secara individu namun berdampak pada tingginya penawaran tenaga kerja berskill yang justru menyebabkan ketimpangan pendapatan. Dengan demikian, pertumbuhan ekonomi Jawa Timur saat ini belum mengarah pada inklusivitas karena semakin tinggi kualitas modal manusia hanya diikuti oleh sebagian masyarakat, namun tidak tersebar secara merata bagi masyarakat miskin.

Dengan menambahkan variabel teknologi yaitu pembiayaan investasi pemerintah untuk investasi pendidikan dan kesehatan maka diperoleh hasil regresi dalam tabel 1. Dimana, setiap kenaikan sebesar $1 \%$ pada pembiayaan pendidikan dan kesehatan akan meningkatkan pertumbuhan ekonomi sebesar $0.28 \%$ dengan asumsi cateris paribus. Hal ini mengindikasikan bahwa pengeluaran pemerintah yang produktif dapat meningkatkan pertumbuhan ekonomi melalui penyediaan layanan kesehatan yang meningkatkan standar hidup masyarakat serta peningkatan kualitas pendidikan yang meningkatkan produktivitas masyarakat.

Untuk memahami bagaimana dampak pembiayaan investasi modal manusia terhadap inklusivitas pertumbuhan di Jawa Timur dilakukan dengan meregresi persamaan kedua. Indeks inklusivitas diukur berdasarkan pada rasio pertumbuhan ekonomi per tingkat ketimpangan pendapatan. Semakin tinggi nilai indeks maka pertumbuhan ekonomi Jawa Timur mengarah pada inklusif, demikian pula sebaliknya semakin 
Gambar 2. Persebaran Kualitas Modal Manusia yang Tidak Merata
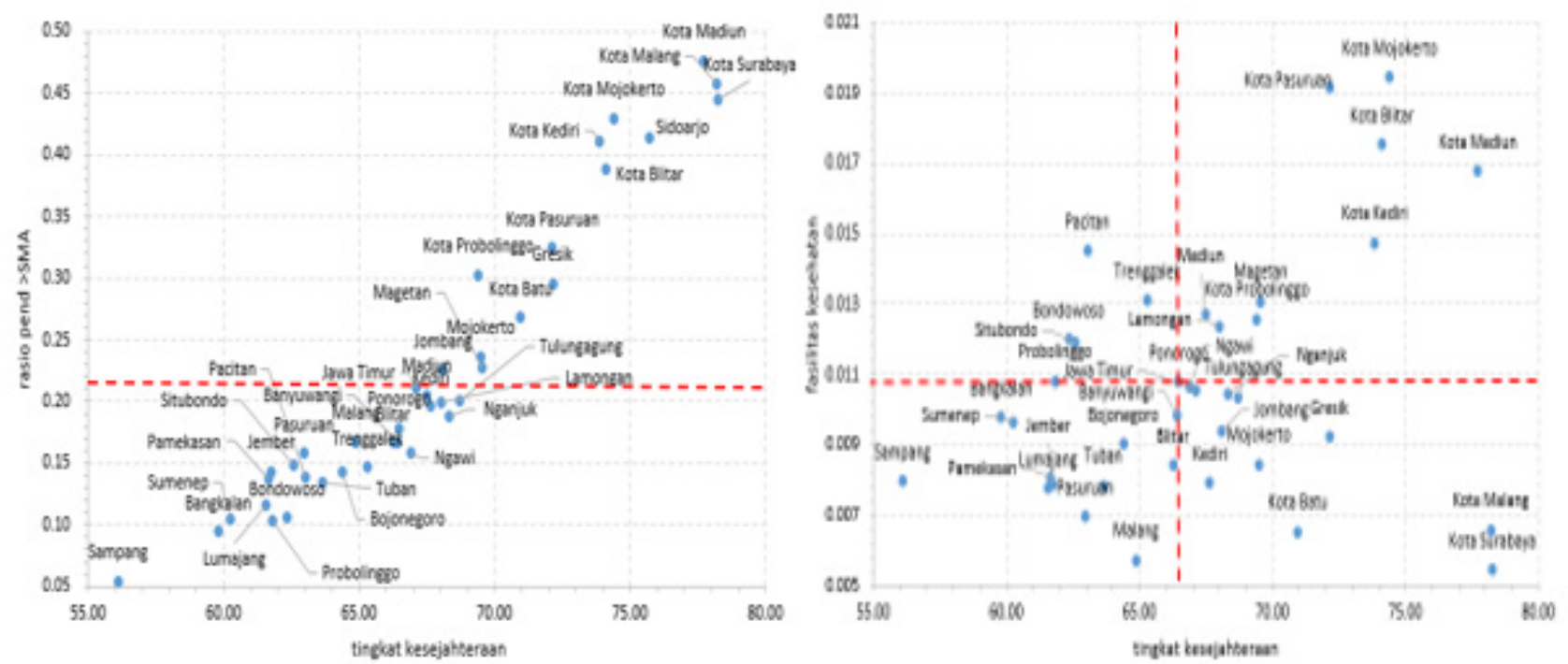

Sumber: BPS Provinsi Jawa Timur, data diolah.

rendah nilai indeks maka pertumbuhan ekonomi tidak inklusif. Berdasarkan perhitungan indeks inklusif, sejak tahun 2013 pertumbuhan ekonomi makin tidak inklusif dan pada akhir 2015 indeks inklusif menunjukan nilai terendah yaitu 12,95.

Hasil statistik menunjukan bahwa pertumbuhan ekonomi masa lampau tidak berhubungan dengan inklusivitas di Jawa Timur. Berdasarkan model persamaan kedua, baik kualitas modal manusia, pembiayaan investasi pendidikan dan pembiayaan investasi kesehatan berpengaruh terhadap inklusivitas pertumbuhan di Jawa Timur. Sejalan dengan persamaan pertama, bahwa kualitas modal manusia di Jawa Timur tidak tersebar secara merata dan justru menyebabkan pertumbuhan ekonomi yang tercipta tidak mengarah pada inklusivitas. Pada persamaan ini, peningkatan kualitas modal manusia sebesar $1 \%$ berdampak pada penurunan indeks inklusivitas sebesar 6\%. Artinya, hanya sebagian tertentu masyarakat dengan tingkat pendidikan, kesehatan dan daya beli yang tinggi yang menikmati adanya pertumbuhan ekonomi. Sehingga indeks inklusivitas cenderung menurun dengan makin berkualitas standar hidup masyarakat golongan tertentu. Gambar 2 memperkuat argumen bahwa kualitas modal manusia yang diukur oleh tingkat pendidikan tinggi (>SMA) dan ketersediaan fasilitas kesehatan masih sangat minim dan terpusat di daerah tertentu seperti di Kota Surabaya, Kota Madiun, Kota Pasuruan, Kota Mojokerto, dan Kota Kediri.

Selanjutnya, dengan membagi pembiayaan investasi modal manusia dalam variabel pembiayaan pendidikan dan pembiayaan kesehatan diketahui bahwa terdapat perbedaan hasil regresi. Dampak pembiayaan investasi modal manusia yang berpengaruh signifikan positif mendorong inklusivitas pertumbuhan di Jawa Timur adalah investasi kesehatan. Signifikan secara statistik berarti memang benar dan dapat dipercaya bahwa adanya perubahan pada pembiayaan investasi pendidikan dan kesehatan akan mampu mempengaruhi pertumbuhan inklusif di Jawa Timur. Hasil temuan menunjukan bahwa setiap peningkatan sebesar $1 \%$ investasi kesehatan akan meningkatkan inklusivitas pertumbuhan sebesar $0,3 \%$. Sebaliknya, setiap peningkatan sebesar $1 \%$ investasi pendidikan justru mengurangi tingkat inklusivitas pertumbuhan sebesar $0,2 \%$. Perbedaan tanda (positif / negatif) pada koefisien akan memberikan pengaruh peningkatan/ penurunan untuk mewujudkan pertumbuhan yang lebih inklusif.

Menurut IWI Report 2014, investasi pada bidang pendidikan dan kesehatan tidak secara langsung dapat meningkatkan output suatu daerah. Investasi pendidikan akan berdampak bagi produktivitas masyarakat melalui peningkatan kemampuan/ skill untuk memproduksi barang/jasa dan bersaing dalam pasar tenaga kerja sedangkan investasi kesehatan berdampak bagi standar hidup tiap orang, usia harapan hidup yang lebih panjang, dan peningkatan produktivitas tenaga kerja. Nilai yang negatif pada pembiayaan investasi pendidikan 
menunjuan adanya persoalan lemahnya produktivitas dan kualitas sektor pendidikan dan efektivitas pembiayaan pendidikan yang ada di Jawa Timur. Hal inilah yang mengakibatkan kapasitas sumber daya manusia rendah dalam hal keahlian kerja dan tingkat pendidikan yang rendah serta kurangnya akses terhadap pendidikan tingkat menengah di Jawa Timur.

\section{Kesimpulan}

Pendefinisian pertumbuhan inklusif yaitu percepatan pertumbuhan ekonomi diikuti dengan peningkatan kualitas sumber daya manusia dan standar hidup yang layak mendorong perencana pembangunan untuk menyusun kebijakan yang tepat dan bermanfaat. Penelitian ini berbasis pada teori yang dikembangkan oleh Lucas (1988) dengan menambahkan variabel investasi modal manusia dalam meningkatkan pertumbuhan ekonomi. Hasil regresi menunjukkan bahwa investasi modal manusia khususnya alokasi anggaran sosial secara positif berdampak pada pertumbuhan ekonomi. Meski demikian, akumulasi modal fisik di Jawa Timur tidak berdampak signifikan terhadap pertumbuhan ekonomi. Temuan ini menggambarkan fenomena melebarnya ketimpangan pendapatan dikarenakan kualitas sumber daya yang tidak tersebar secara merata. Aksesibilitas pendidikan, kesehatan dan pendukung standar hidup tidak dirasakan oleh masyarakat miskin.

Penelitian ini ditutup dengan sebuah kesimpulan bahwa modal manusia adalah kunci pembentukan kesejahteraan yang inklusif karena investasi yang diarahkan akan secara langsung berdampak untuk mendorong pembangunan modal manusia (peningkatan kualitas pendidikan, gaji guru dan pendidikan, peningkatan kuantitas ratarata bersekolah, peningkatan standar hidup, usia harapan hidup yang lebih panjang, dan produktivitas bekerja). Meski demikian terdapat persoalan lemahnya produktivitas sektor pendidikan dan efektivitas dalam pembiayaan investasi pendidikan. Pembiayaan investasi pendidikan masih terbatas pada peningkatan kuantitas namun lemah dalam peningkatan kualitas pendidikan sehingga kapasitas sumber daya manusia masih rendah untuk mengupayakan percepatan pertumbuhan inklusif di Jawa Timur.
Referensi

Anand, R., Mishra, S., \& Peiris, S. J. (2013).

Inclusive Growth Revisited: Measurement

and Determinants. International Monetary Fund - Asia Pasific Department (Vol. 122). https://doi.org/10.5089/9781484323212.001 Bank Indonesia. 2016. Kajian Ekonomi Regional Jawa Timur Triwulan 2016. http:// www.bi.go.id/id/Default.aspx

Bank Dunia. 2011. Diagnosa Pertumbuhan Ekonomi Jawa Timur: Mengidentifikasi Hambatan-Hambatan Utama Pertumbuhan yang Inklusif di Provinsi Terbesar Kedua di Indonesia. Jakarta: Bank Dunia.

Bhattacharyya, S and Resosudarmo, B P. 2014. Growth, growth accelerations, and the poor: lessons from Indonesia. World Development, (Vol. 66): 154-165.

Burja, C., \& Burja, V. (2013). Education's contribution to sustainable economic growth in Romania. Procedia - Social and Behavioral Sciences, 81, 147-151. https:// doi.org/10.1016/j.sbspro.2013.06.403 Klasen, Stephan. 2010. Measuring and Monitoring Inclusive Growth: Multiple Definitions, Open Questions, and some Constructive Proposals. ADB Sustainable Development Working Paper Series No. 12. Kuncoro, Mudrajat. 2006. Ekonomika Pembangunan Teori, Masalah, dan Kebijakan (Edisi Keempat). Yogyakarta: UPP STIM YKPN.

Mandlebe, W. (2014). Human Capital and Inclusive Growth: A Case Study of Botswana. Walden University. https://doi. org/10.1111/j.1467-8616.2008.00521.x Malik, Pandey, J. K., Chintu, A. K., \& Ranjan, R.

(2014). Inclusive Growth In India : Some Empirical Facts. Jurnal Knowledge HorizonsEconomics, 6(1), 2069.

[Prentice Hall, Greene] Econometric analysis, 5th ed.pdf. (n.d.).

Richard Samans, Jennifer Blanke, Gemma Corrigan, M. D. (2015). The Inclusive Growth and Development Report. Retrieved from http://www3.weforum.org/docs/Media/ WEF_Inclusive_Growth.pdf Samans, R., Blanke, J., Corrigan, G., \& Drzeniek, M. (2015). Benchmarking Inclusive Growth and Development Discussion Paper. 
Switzerland.

Sen, K. (2014). Inclusive growth: When may we expect it? when may we not? Asian Development Review, 31(1), 136-162. https://doi.org/10.1162/ADEV_a_00022 Stata Corporation. (2001). Stata reference manual : release 7 (Vol. 3).

UNU-IHDPP and UNEP. 2014. Inclusive Wealth Report 2014 Measuring progress toward sustainability: Cambridge University Press.

Lampiran:

Rule of Identification:

Jumlah $\mathrm{K}=8$

Jumlah $\mathrm{k}=6$

Jumlah $\mathrm{M}=2$

Sehingga $(K-k)>(M-1)=2>1$ (over-identified).

Persamaan ini dapat diuji secara simultan.

Hasil Regresi

\begin{tabular}{|c|c|c|c|c|c|c|}
\hline Equation & $O b=$ & Daxma & pars $\equiv$ & $m p-a q^{*}$ & $c h 12$ & $D$ \\
\hline gr & 12 & 5 & .0210514 & 0.4624 & $11-16$ & 0.0482 \\
\hline
\end{tabular}

\begin{tabular}{|c|c|c|c|c|c|c|}
\hline & Coet. & std. Exx. & $\mathbf{z}$ & $P>1=1$ & c9ss Cont. & Intexvalu \\
\hline \multicolumn{7}{|l|}{$g x$} \\
\hline$g=0$ & -1341855 & .2350771 & 0.57 & 0.568 & -.3265571 & .5949282 \\
\hline cap & -1919392 & .2416055 & 0.79 & 0.427 & -.2815988 & .6654773 \\
\hline man & -4.436508 & 2.20176 & -2.01 & 0.044 & -8.751878 & -.1211385 \\
\hline gued & -.2169272 & .1083316 & -2.00 & 0.045 & -.4292533 & -.0046012 \\
\hline gue & .2806173 & .0913914 & 3.07 & 0.002 & .1014935 & .4597412 \\
\hline$-\infty e n=$ & 5.898861 & 2.275616 & 2.59 & 0.010 & 1. 438735 & 10.35899 \\
\hline \multicolumn{7}{|l|}{$i x$} \\
\hline$g x=$ & -.0455678 & .2847673 & -0.16 & 0.873 & -.6037016 & .5125659 \\
\hline $\operatorname{man}$ & -6.256363 & 1.298728 & -4.82 & 0.000 & -8.801822 & -3.710903 \\
\hline gued & -.2205179 & .0855804 & -2.58 & 0.010 & -.3882524 & -.0527834 \\
\hline guhe & -3191333 & .0736971 & 4.33 & 0.000 & -1746897 & -4635769 \\
\hline$-\operatorname{con}=$ & 11.55727 & 2.28364 & 5.06 & 0.000 & 7.081422 & 16.03313 \\
\hline
\end{tabular}

